\title{
ON EXTENSIONS AND APPLICATIONS OF THE BEESACK INEQUALITY FOR BOUNDING RIEMANN-STIELTJES INTEGRALS
}

\section{P. CERone}

Abstract. A variety of sharp generalisations and extensions of a Beesack inequality are investigated in the current development. A number of applications are examined, including bounding a renewal integral equation which arises in risk/ruin problems. Sharp and tighter bounds than existing results for the Čebyšev functional involving Riemann-Stieltjes integrals are also determined which is of importance in many applications including in providing bounds for perturbed quadrature rules.

Mathematics subject classification (2010): 26D15, 41A17.

Keywords and phrases: Riemann-Stieltjes integral, Volterra integral equations, integral inequalities, Čebyšev functional, bounds.

\section{REFERENCES}

[1] T. M. Apostol, Mathematical Analysis, Addison-Wesley Publishing Comp., Reading, Massachusetts, $2^{\text {nd }}$ Ed., 1975.

[2] P. R. BEESACK, Bounds for Riemann-Stieltjes integrals, Rocky Mountain J. Math., 5 (1) (1975), 7578.

[3] N. BARnetT And S. S. Dragomir, The Beesack-Darst-Pollard inequalities and approximations of the Riemann-Stieltjes integral, Applied mathematics Letters, 22 (2009), 58-63.

[4] P. Cerone, On an Identity for the Chebychev Functional and Some Ramifications, J. Ineq. Pure and Applied Math., 3 (1) (2002), Art. 4, online http://www.emis.de/journals/JIPAM/ article157.html?sid=157.

[5] P. Cerone And S. S. Dragomir, Bounding the Čebyšev functional for the Riemann-Stieltjes integral via a Beesack inequality and applications, Computers and Mathematics with Applications, 58 (6) (2009), 1247-1252.

[6] D. C. M. Dickson, Insurance Risk and Ruin, Cambridge University Press, 2005.

[7] R. Darst and H. Pollard, An inequality for the Riemann-Stieltjes integral, Proc. Amer. Math. Soc., 25 (1970), 912-913.

[8] S. S. DRAGOMIR, Sharp bounds of Čebyšev functional for Stieltjes integrals and applications, Bull. Austral. Math. Soc., 67 (2003), 257-266.

[9] S. S. Dragomir, New estimates of the Čebyšev functional for Stieltjes integrals and applications, J. Korean Math. Soc., 41 (2) (2004), 249-264.

[10] S. S. DRAGOMIR, Inequalities of Grüss type for the Stieltjes integral and applications, Kragujevac J. Math., 26 (2004), 89-122.

[11] S. S. Dragomir And Th. M. Rassias, Ostrowski Type Inequalities and Applications in Numerical Integration, Kluwer Academic Publishers, Dordrecht, 2002.

[12] S. LuCAS, Approximation to $\pi$ Derived from Integrals with Nonnegative Integrands, The American Mathematical Monthly, American Mathematical Society, (2005), 166-172. 